\title{
Quality of Craft Made of Clothing Industrial Waste In Makassar, Indonesia
}

\author{
Hamidah Suryani ${ }^{1}$, Muhammad Yahya ${ }^{1}$, Andriany Ningsih Taufieq ${ }^{2}, \mathrm{Jalwiah}^{2}$, Murniati $^{2}$ \\ ${ }^{1}$ Universitas Negeri Makassar, South Sulawesi, Indonesia \\ ${ }^{2}$ Madrasah Aliyah Negeri 1 Makassar, South Sulawesi, Indonesia
}

\begin{abstract}
The study aims at exploring the craft quality made of clothing industrial waste in Makassar. This type of research is quantitative approach with three variables: design, materials, and finishing. Samples are 50 craft products are evaluated by five craft experts. Craft quality score is calculated based on the average from expert respond and divided into four categories. Crafts quality for design and materials variables are very low and only a small number has high quality. The finishing quality of crafts generally has high category and only $12 \%$ of crafts with the very low category. The kinds of craft which a very low quality are pot holder and doormats.
\end{abstract}

Keywords: Craft, industrial waste, quality

\section{Introduction}

The clothing industry is growing rapidly by the growth of human population. The apparel production continues by the needs of consumers. However, in the process industry also generated waste as a side effect. Various type of waste in apparel industry such as rags, thread, paper and paint dye from the fabric. Inefficiencies in the production process could lead to the large volume of waste generated from the raw materials, additives, and production [1][2][3]. Rag or patchwork can be reused to make other useful materials. The effort supports the reduction of the volume of waste.

Utilization of patchwork as crafts have long been known in the world. Recycling efforts patchwork as innovative household products found in various countries. In Sweden, the use of patchwork has been known since 1820. The technique used is a mosaic, applique, and quilting. Various household goods produced in this craft. Motivation to utilize waste cloth is dominant by economic interest compared with aesthetic purposes. Fabrication techniques from more than economic. [4] In China, the use patchwork recorded on some dynasty with various aspects considered, namely fabric and color, shapes and uses. The functions of the various craft related to cultural and Buddhism "Penance" concept [5].

In Makassar, use of patchwork in the craft business has also grown since several decades ago. However, the shape and the quality is very limited. Most of the crafts are pot holder doormats. Quality reviewed on three things: the design, finishing, and material. The quality of the crafts expressed through creative interaction with materials and the practical benefits, aesthetic tastes, and socio-economic needs of public. [6]. Many kinds of material are used in the craft. Availability of materials with varying color and size lead the craftsmen to combine different types of materials. Also, the effluent quality fabric is also affected by the craft quality. In the finishing process of crafting, product durability into consideration. The fashion industry can be involved in environmental sustainability effort by making durable fabrics. [7].

\section{Research Methods}

This research used quantitative approach. Quality assessment is reviewed on three variables: design, materials, and finishing. Each consisting of three indicators (Table 1). Assessment of quality is done by five people crafting expert with a focus on 50 craft products that utilize industrial waste clothes in Makassar. Data analysis was held by assessing each indicator with the numbers from 1 (very low) to 4 (very high). Scoring is the sum of an indicator value for each expert.

Table 1: Description of variables, Indicators, and Scoring

\begin{tabular}{|c|c|l|}
\hline Variable & Indicators & Scoring Average \\
\hline Design & Innovation & $3,0-5,5=$ Very low \\
& Art & $5,6-8,0=$ Low \\
& Technique & $8,1-10,5=$ High \\
\hline Material & Combination & $10,6-12,00=$ Very high \\
& Material & \\
& Color & \\
\cline { 1 - 2 } Finishing & Sewing Technique & \\
& Neatness & \\
& Durability & \\
&
\end{tabular}

\section{Result and Discussion}

\subsection{Description of Craft}

The identification crafts describe that most product is made by patchwork techniques. This technique is the art of sewing skills by combining pieces of leftover fabric accordance with the desired pattern by hand or machine. Patchwork techniques characteristic appears on the way the merger of the industrial waste. Various objects can be created with a patchwork technique by compiled into alloys and produce good quality (Figure1) 


\section{International Journal of Science and Research (IJSR) \\ ISSN (Online): 2319-7064}

Index Copernicus Value (2015): 78.96 | Impact Factor (2015): 6.391

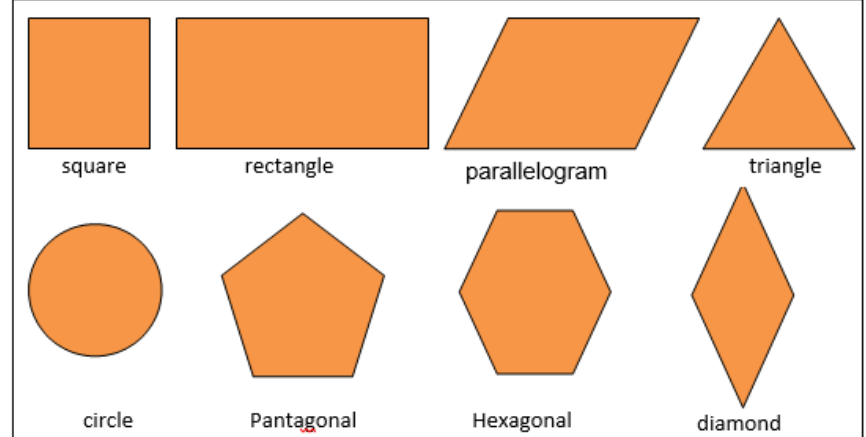

Figure 1: Basic Shape of Patchwork

The series of the basic form of patchwork arranged with different colors and various pattern to produce a high artistic value. Many crafts are resulted with combining two types of patterns (circle pattern with box pattern). There also are combining the two categories of materials (silk and cotton). Many products as a useful craft in Makassar showed in figure 2 .

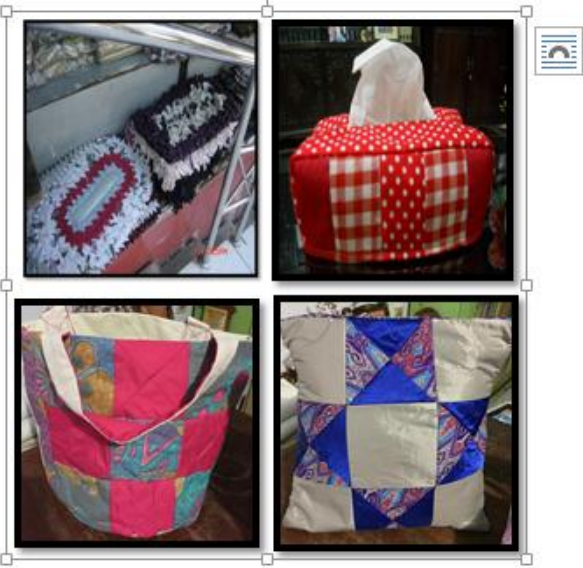

Figure 2: Crafts from waste fabric in Makassar

Type crafts were obtained in 50 craftsmen are grouped by eight types as its functions. (Table 2. Most of the craft is pot holder, and only a few craftsmen made wall decoration

Table 2: Description usage of crafting

\begin{tabular}{|c|c|c|}
\hline Usage & Number & Percentage \\
\hline Pot holder & 12 & 24 \\
\hline Doormats & 8 & 16 \\
\hline Tissue Packing & 6 & 12 \\
\hline Phone Packs & 4 & 8 \\
\hline seat cushions & 6 & 12 \\
\hline Tablemate & 4 & 8 \\
\hline wall decoration & 2 & 4 \\
\hline bag & 8 & 16 \\
\hline Total & 50 & 100 \\
\hline
\end{tabular}

Most craftsmen using waste into useful materials in consideration of easy preparation and length of working. Economically, it is extremely beneficial because of the cost of production and sales of small relate easy. Artisans sew bags, and wall decoration are based on customer orders.

\subsection{Quality of Design}

The quality of craft design which made from industrial waste based on three indicators (innovation, art, and technique).
Innovation is assessed on additional new artistic compared to the previous layout. The value of art based on a mix of colors, shapes and arrangement patterns that artistic produce. The technique is a way to combine and arrange various patterns and levels of difficulty workmanship.

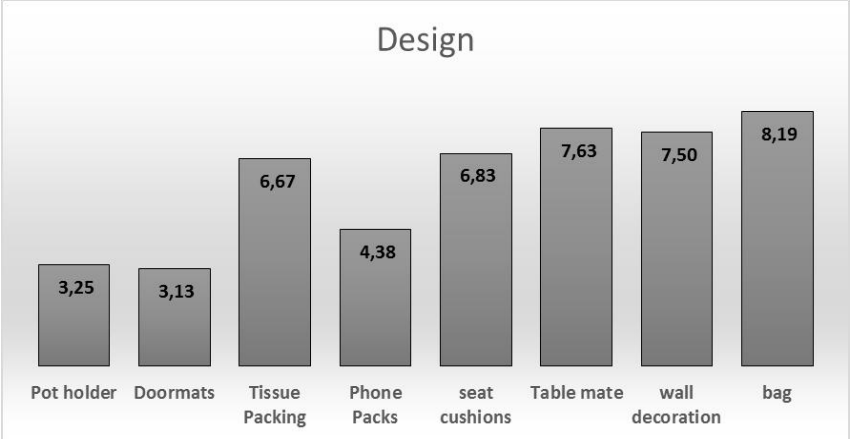

Figure 3: Score of Crafts Design

Figure 3 shows that pot holders, doormats and phone packs rated between 3.0 to 5.5 or with very low category. Tissue packing, seat cushion, table mate and wall decoration indicate a value between 5.6 to 8.0 or lower-quality design. The bag has a value of 8.19 between the value of 8.1 to 10.5 or has a high-quality design. The image shows the percentage distribute crafting the design quality category.

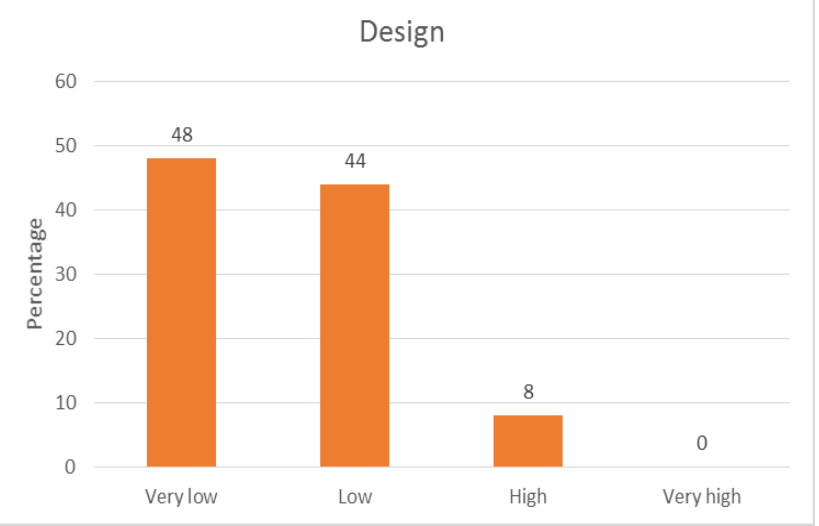

Figure 4: Distribution of design category

Figure 4 reveals that $48 \%$ of crafts in very low category and $44 \%$ have the design of low quality. There is only $8 \%$ craft have a high-quality design. In general, the picture .. shows that most of the crafts have very low quality. In associated with the type of crafts, only bag type has high value.

\subsection{Quality of Material}

Quality materials are rated at combining, the quality of raw materials and colors. Patchwork right combination is similar to the type of material. Textile materials commonly used in character semisynthetic or base ingredients derived from plants with a mixture of chemicals that are chemically treated. For example cotton, Tetron, and others. There is also a synthetic material, textile material which is essentially derived from a mixture of chemicals with chemicals. For example Dacron, Orlon, and nylon. In addition to the type of textile, fabric motif in the manufacturer of craft products can be realized patchwork of alloy patchwork motif or color patchwork. This is one of the main attractions on the making

\section{Volume 6 Issue 7, July 2017 www.ijsr.net}




\section{International Journal of Science and Research (IJSR) \\ ISSN (Online): 2319-7064}

Index Copernicus Value (2015): 78.96 | Impact Factor (2015): 6.391

of handicraft products patchwork. Motif patchwork can be selected that geometric patterns such as a pattern of lines, boxes, and polka dots, organic motifs such as floral and star and abstract motifs. (Fig.5)

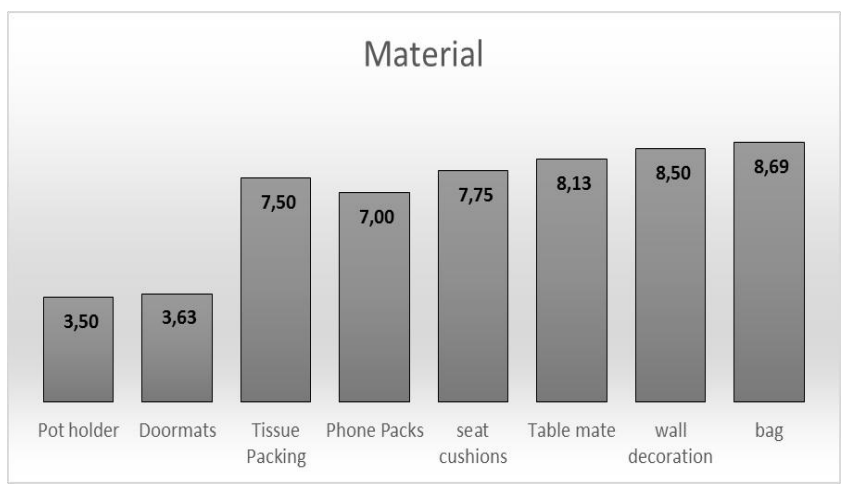

Figure 5: Score of Crafting Material

Figure 5 shows that the pot holder doormats have a material value between 3.0 to 5.5 or with very low category. Tissue packing, phone and seat cushion packs worth between 5.6 to 8.0 or lower-quality design. Table mat, wall decoration, and Bag has a value between the values of 8.1 to 10.5 , or have a high material quality. Figure 6 shows the percentage distribute crafting in the category of quality material.

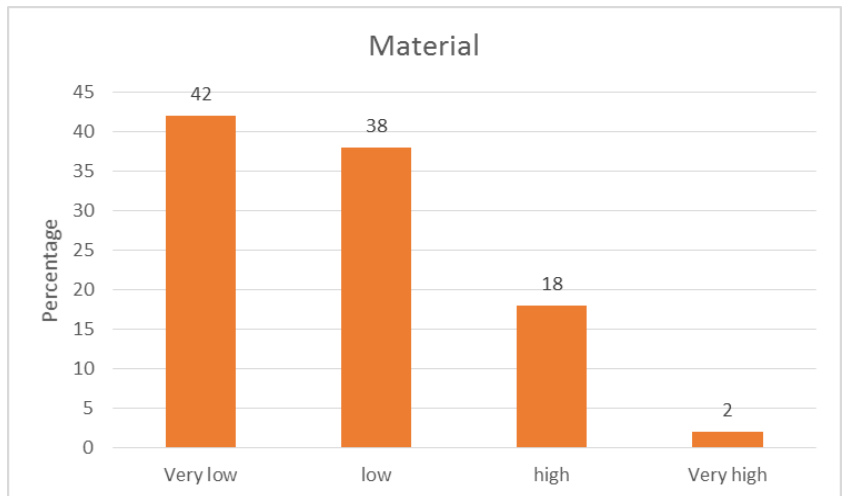

Figure 6: Distribution of Material Category

Figure 6 indicates that the pot holder doormats have a tangible value between 3.0 to 5.5 or with very low category. Tissue packing, phone and seat cushion packs worth between 5.6 to 8.0 or lower-quality design. Table mat, wall decoration, and Bag has a value between the values of 8.1 to 10.5 , or have a high material quality. Figure 6 shows the percentage distribute crafting in the category of quality material.

\subsection{Quality of Finishing}

Finishing crafting rated by sewing technique, neatness, and durability. In sewing techniques, there are craftsmen who use the unisex machine and by hand. Sewing by hand to produce a variety of high-quality crafting. Durability crafting durability result indicated by crafting or sewing products strength and strength of materials crafting general. Figure 7 shows the quality finishing of crafting.

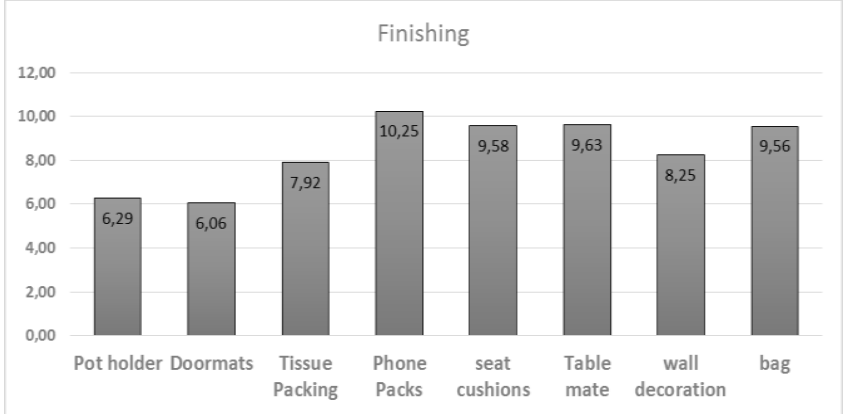

Figure 7: Score of Crafting Finishing

Figure 7. reveals that the potholder and doormats assessed with low quality or value of between 5.6 to 8.0. Other types of crafting that phone packs, seat cushion, table mate, wall decoration and the bag have a high material quality. Figure 8 shows the percentage distribute crafting in the category of quality finishing

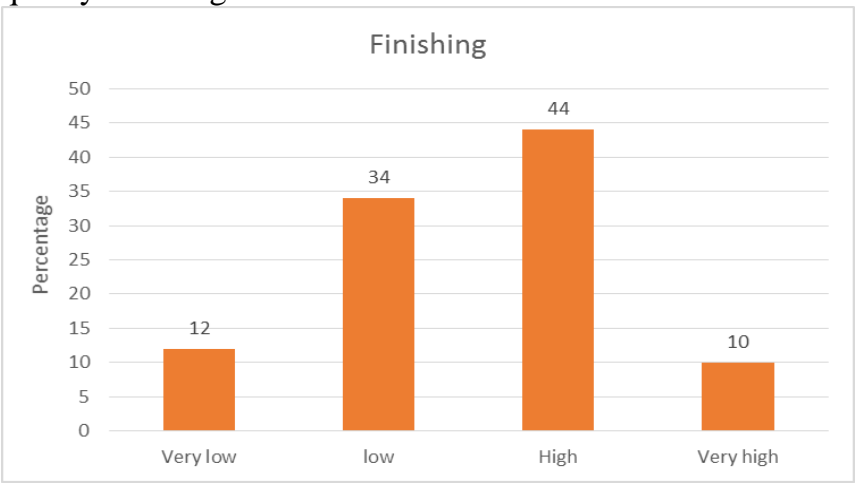

Figure 8: Distribution of finishing category

Figure 8 indicates that most crafting high-quality finishing $(44 \%)$ and there is also a $10 \%$ crafting the very high value. This indicates that the sewing technique in crafting qualify finishing quality. Similarly, the neatness and durability.

\subsection{Discussion}

Handicrafts made of patchwork in Makassar growing limited and low product innovation. Unlike the kind of patchwork in China that kind developed by the community. Unlike the kind of patchwork in China that kind prepared by community needs. Its development is connected with its beauty and the desire of people to pray for a better life.As a part of traditional crafting, government and society keep the patchwork in life. [5]. Furthermore, Outlining other benefits of Crafting Textiles than as an economic resource but also can support social sustainability. In the production of crafting, artisans not only worked alone but supported by industries [8].

Various techniques have also been developed to manufacture of crafting so that innovation can be better results and the resale value will be higher. Thus the interest of society to develop results-based craft patchwork waste will be higher. One of the creative efforts and normative can be done to reduce the negative impact of the waste apparel industry, is to use the approach to reduce, reuse and recycle (3R). 


\section{Conclusion}

The results showed that quality craft is minimal in design and material. There is no craft with very high design quality, and only $2 \%$ is a craft with solid material. Design quality. The maximum quality of design and material is a bag. Finishing of craft is generally in good quality. Furthermore type of craft that has the highest quality of finishing is phone packs.

\section{References}

[1] A. Kozlowski, M. Bardecki, and C. Searcy, "Environmental impacts in the fashion industry: A lifecycle and stakeholder framework," J. Corp. Citizsh., no. 45, p. 17, 2012.

[2] A. Susanty, S. Hartini, D. Puspitasari, and P. Arsiwi, "Measuring Efficiency of Using Resource in the Production Process of Making Stamped-Batik: A DEA Approach," Mediterr. J. Soc. Sci., vol. 6, no. 5, p. 318, 2015.

[3] L. C. Maia, A. C. Alves, and C. P. Leão, "Sustainable Work Environment with Lean Production in Textile and Garment Industry," in Proceedings of International Conference on Industrial Engineering and Operations Management (ICIEOM2012), 2012, pp. 9-11.

[4] S. L. Rikert, S. S. Harp, P. E. Horridge, and J. L. Shroyer, "Documentation of Swedish patchwork quilts: 1830 to 1929," Cloth. Text. Res. J., vol. 17, no. 3, pp. 134-143, 1999.

[5] M. A. O. Huiwei, "Source tracing and anlaysis of traditional Chinese patchwork [J]," J. Text. Res., vol. 9, p. 28, 2010.

[6] S. Bardzell, D. K. Rosner, and J. Bardzell, "Crafting quality in design: integrity, creativity, and public sensibility," in Proceedings of the Designing Interactive Systems Conference, 2012, pp. 11-20.

[7] F. Caniato, M. Caridi, L. Crippa, and A. Moretto, "Environmental sustainability in fashion supply chains: An exploratory case based research," Int. J. Prod. Econ., vol. 135, no. 2, pp. 659-670, 2012.

[8] K. Kuusk, O. Tomico, G. Langereis, and S. Wensveen, "Crafting Smart Textiles-a meaningful way towards societal sustainability in the fashion field?," 2012. 